\title{
Comparative analysis of damage to sewer rehabilitation coatings
}

\author{
Andrzej Kuliczkowski ${ }^{1}$, and Stanisław Nogaj ${ }^{*}$ \\ ${ }^{1}$ Kielce University of Technology, Faculty of Environmental, Geomatic and Energy Engineering, 25- \\ 314 al. Tysiąclecia Państwa Polskiego 7, Poland
}

\begin{abstract}
Technologies for the trenchless rehabilitation of pipelines using various types of coatings have been used for almost half a century. Considering that the assumed life expectancy of such renewed pipelines is 50 years, it will be necessary to assess their technical condition in the near future. The aim of this article is to attempt to answer the question "Do existing damage classification methods allow for the full and reliable assessment of the sewers already renewed with rehabilitation coatings?". The scope of the article, and its original part, is to describe how the problem of damage assessment of rehabilitation coatings has been included in various methods of classification of underground infrastructure pipelines, and conducting a comparison that compares these methods in terms of the damages described. An interpretation of the results of the research on rehabilitation coatings operated in various time periods, starting from those recently applied to those operating for over 30 years, was also made. The result of the analysis is to present the differences and deficiencies in the damage classification methods discussed.
\end{abstract}

\section{Introduction}

Technologies for the trenchless rehabilitation of sewage pipes using various types of coatings have been used for almost half a century. The first implementation related to the most popular technology of rehabilitation of sewage pipes - cured-in-place pipe (CIPP) took place in 1971 in Great Britain [1]. These coatings are used when the exploited pipeline, for reasons such as corrosion or cracks, ceases to be functional and, for example, it is threatened with a loss of stability and, as a result, collapse. The thickness of the coating depends on whether the coating is a non structural rehabilitation, and thus protects the pipe against abrasion of the bottom and the walls of the sewer, internal corrosion, encrustation and improves hydraulic parameters and the sealing of the pipe; or, is a fully structural rehabilitation, i.e. a rehabilitation coating alone, or in cooperation with the existing pipe replaces it in terms of static and strength, i.e. transfers the external loads acting on the structure and, if necessary, forces caused by the pressure prevailing in the pipe [2,3].

There are many methods of sewerage pipe classification, which uses data obtained from CCTV inspection, including regarding, for example, the size and location of cracks, the

\footnotetext{
${ }^{*}$ Corresponding author: stanislawnogaj@gmail.com
} 
infiltration of groundwater, root overgrowth into the interior of the sewer or a covering of the pipe cross section by bottom deposits, etc. On this basis many methods allow you to assess whether the damage is a threat and the pipeline needs immediate rehabilitation or if it can be postponed. Rehabilitation coatings are designed for a period of 50 years, so taking into account that their first application took place 46 years ago, in the near future such an evaluation will have to be subjected to already renovated pipelines [4-6].

The purpose of this article was to determine whether current methods allow for a full and reliable assessment of the state of rehabilitation coatings. To answer this question, we described how the problem of the damage assessment of rehabilitation coatings was included in various classification methods, i.e. the assignment of damage to sewage pipes to the defect categories defined therein, such as cracks or a shrinkage of the coating, and a comparative analysis of methods for the described damage. The original element of this publication is the presentation of differences and gaps in the analyzed methods. Reference was also made, among others, to the results of a study [7,8] conducted in the United States regarding a retrospective assessment of the technical condition of sewage pipes subjected to cured-inplace pipe rehabilitation (CIPP) in the period from 5 to 34 years earlier.

\section{Methods}

\subsection{Methodology for conducting an assessment of the technical condition of the pipelines}

Only some methods of sewerage pipe classification contain descriptions of damage to rehabilitation coatings [9-12], and is connected with the erroneous assumption that renewed pipes will not require evaluation until the end of their life expectancy, and any irregularities can be eliminated at the assembly stage and shortly after their completion.

In all of the considered methods, the starting point for the description of damages occurring in the pipeline is the inspection results made with an inspection vehicle equipped with a CCTV camera after prior cleaning of the pipeline from deposits or accumulated fats. Such a vehicle, depending on the level of its technological advancement, allows, for example, $[3,13]$ the registration of longitudinal pipeline drop, horizontal and vertical rotation of the camera, recording video and taking photos or recording the distance traveled along the checked cable. Then, the documentation from the inspection carried out in the form of photographs and video is analyzed, as a result of which all observed damage and irregularities are given a code, characteristic for the coding system of the given method. The coding system is a way of describing damages, by means of letters and numbers, enabling the assignment of a given damage to a specific category. The methods analyzed in this study which are current versions of damage classification are presented below.

\subsection{British method}

The classification of damage to sewage pipes was developed by the Water Research Center (WRc). The basis for the development of this method was a manual on methods for the restoration of sewers (Sewerage Rehabilitation Manual), which was presented in 1978 [14], i.a. and based on it in 1980 the first version of the Manual of Sewer Condition Classification [9] was created. It contains, i.a. recommendations regarding the correct method for conducting CCTV inspections, the methodology of defect description using the developed coding system a description of the form for correct description of damages, codes for individual damage to sewage pipes, laterals, rehabilitation coatings, hatches and sewer manholes [10]. It allows describing damage to rehabilitation coatings in terms of damage 
type, system, longitudinal location of the damage (abbrev. LLoTD), damage length and its repeatability (for selected damage) (abbrev. DLaR) and clock reference damage location (abbrev. CRDL).

\subsection{American method}

The American method [9] was developed by the National Association of Sewer Service Companies (NASSCO) in the USA. This classification of damage to sewage pipes is based on the experiences of the entrepreneurs associated with this organization and on the assumptions contained in the Manual of Sewer Condition Classification 5th Edition described above [10]. According to the authors [9], this method, also modeled on other classifications, unifies the damage described in them and ensures their coherent and credible categorization. It contains, i.a. the authors' opinion on the need to categorize damage associated with sewer networks, methodology for describing operational and structural damage by means of a developed coding system, a description of the form for the description of damages, codes of individual sewer system damage, laterals, rehabilitation coatings, hatches and sewage manholes. It allows describing damage to rehabilitation coatings in terms of damage type, coding system, longitudinal location of the damage, damage length and its repeatability (for selected damage) and clock reference damage location.

\subsection{New Zealand method}

This method was developed by the company ProjectMax Ltd on behalf of the New Zealand Water and Wastes Association [11], in cooperation with, i.a. Drainage Managers' Group, Neztech Systems Ltd. and Wellington Water Management Ltd. This method describes, i.a. the impact of data obtained from CCTV inspections on the assessment of the technical condition of sewerage pipes, recommendations for the correct performance of CCTV inspections, description of devices used in TV inspection, a methodology to describe defects using a developed coding system and codes for individual sewer system damage, laterals and rehabilitation coatings. It allows to describe damage to rehabilitation coatings in terms of damage type (only in the form of a comment; abbrev. DTCOM), coding system, longitudinal location of the damage, damage length and its repeatability (for selected damage), clock reference damage location and percentage of cross-section area loss (abbrev. PCSAL) where: $\leq 10 \%$ (small), $>10 \%$ to $<25 \%$ (medium), $\geq 25 \%$ (large) cross-section area loss.

\subsection{European method}

This is a European norm from 2003 with the status of a Polish standard since 2006 [12]. It contains, i.a. the methodology of defect description using the developed coding system, a description of the form for the correct description of damages, codes for individual damage to sewage pipes, laterals, rehabilitation coatings and sewage manholes. It allows describing damage to rehabilitation coatings in terms of damage type, coding system, longitudinal location of the damage, damage length and its repeatability (for selected damage), clock reference damage location and percentage of cross-section area loss. 


\section{Results}

\subsection{Comparative analysis of damages of rehabilitation coatings in the analyzed methods}

The damage classification methods listed in point 2 are the most commonly used in North America, Europe and Australia and Oceania. In order to perform a comparative analysis of the four previously described classification methods, a summary of the damages described in them was prepared along with the defined methods of their description (Table 1).

Table 1. List of damage to rehabilitation coatings in the discussed methods (LLoTD longitudinal location of the damage, DLaR - damage length and its repeatability, CRDL - clock reference damage location, PCSAL - percentage cross-section area loss, DTCOM - describes damage type in the form of a comment).

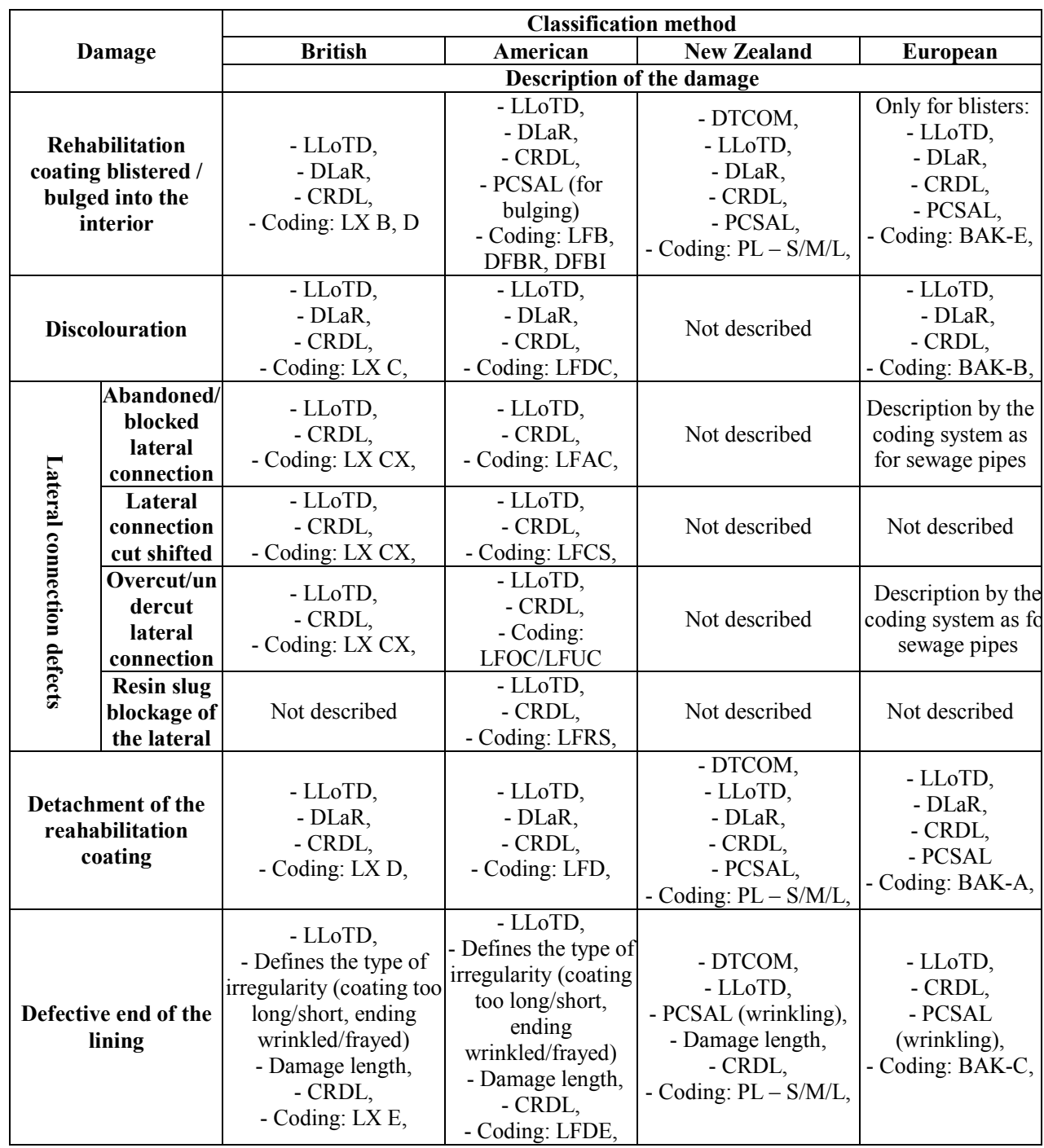




\begin{tabular}{|c|c|c|c|c|}
\hline $\begin{array}{l}\text { External bulge of the } \\
\text { rehabilitation coating }\end{array}$ & $\begin{array}{l}\text { - LLoTD, } \\
\text { - DLaR, } \\
\text { - CRDL, } \\
\text { - Coding: LX EB, }\end{array}$ & Not described & $\begin{array}{c}\text { - DTCOM, } \\
\text { - LLoTD, } \\
\text { - DLaR, } \\
\text { - CRDL, } \\
\text { - Coding: PL - S/M/L, }\end{array}$ & Not described \\
\hline \begin{tabular}{|c|} 
End of the coating \\
not attached to the \\
end of the original \\
pipeline or to the well \\
walls \\
\end{tabular} & $\begin{array}{c}\text { - LLoTD, } \\
\text { - Coding: LX ES, }\end{array}$ & Not described & Not described & Not described \\
\hline \begin{tabular}{c|} 
Dissection of the \\
rehabilitation coating
\end{tabular} & $\begin{array}{c}\text { - LLoTD, } \\
\text { - CRDL, } \\
\text { - Coding: LX F, }\end{array}$ & $\begin{array}{c}\text { - LLoTD, } \\
\text { - CRDL, } \\
\text { - Coding: LFDL, }\end{array}$ & Not described & Not described \\
\hline $\begin{array}{c}\text { Hole in the surface of } \\
\text { the lining }\end{array}$ & $\begin{array}{c}\text { - LLoTD, } \\
\text { - CRDL, } \\
\text { - Coding: LX H, }\end{array}$ & Not described & Not described & Not described \\
\hline $\begin{array}{l}\text { Lining insufficiently } \\
\text { saturated with resin }\end{array}$ & $\begin{array}{c}\text { - LLoTD, } \\
\text { - CRDL, } \\
\text { - Coding: LX R, }\end{array}$ & Not described & Not described & Not described \\
\hline $\begin{array}{c}\text { Excess resin blocking } \\
\text { the flow }\end{array}$ & Not described & $\begin{array}{c}\text { LLoTD, } \\
\text { - DLaR, } \\
\text { - CRDL, } \\
\text { - Coding: LFRS, }\end{array}$ & Not described & Not described \\
\hline Cracks, crevices & \begin{tabular}{|c|} 
- LLoTD, \\
- Defines the type of the \\
crack (longitudinal - L, \\
circumferential - C, \\
complex - M, spiral -H) \\
- DLaR, \\
- CRDL, \\
- Coding: LX S, \\
\end{tabular} & Not described & Not described & Not described \\
\hline $\begin{array}{c}\text { Insufficient curing of } \\
\text { the coating }\end{array}$ & $\begin{array}{c}\text { - LLoTD, } \\
\text { - DLaR, } \\
\text { - CRDL, } \\
\text { - Coding: LX SE, }\end{array}$ & Not described & Not described & Not described \\
\hline $\begin{array}{c}\text { Exposed seam of the } \\
\text { coating }\end{array}$ & $\begin{array}{c}\text { - LLoTD, } \\
\text { - DLaR, } \\
\text { - CRDL, } \\
\text { - Coding: LX SS, }\end{array}$ & Not described & Not described & Not described \\
\hline Coating wrinkled & \begin{tabular}{|c|} 
- LLoTD, \\
- Defines the type of \\
wrinkling \\
(longitudinal- L, \\
circumferential - C, \\
complex - M, spiral -H) \\
- DLaR, \\
- CRDL, \\
- Coding: LX W, \\
\end{tabular} & $\begin{array}{l}\text { - LLoTD, } \\
\text { - DLaR, } \\
\text { - CRDL, } \\
\text { - Coding: LFW, }\end{array}$ & $\begin{array}{c}\text { - DTCOM, } \\
\text { - LLoTD, } \\
\text { - DLaR, } \\
\text { - CRDL, } \\
\text { - PCSAL, } \\
\text { - Coding: PL - S/M/L, }\end{array}$ & $\begin{array}{c}\text { - LLoTD, } \\
\text { - DLaR, } \\
\text { - Defines the type } \\
\text { of wrinkling } \\
\text { (longitudinal - A, } \\
\text { circumferential - } \\
\text { B, complex - C) } \\
\text { - CRDL, } \\
\text { - PCSAL, } \\
\text { - Coding: BAK-D, }\end{array}$ \\
\hline $\begin{array}{c}\text { Bending the coating } \\
\text { outside }\end{array}$ & Not described & $\begin{array}{l}\text { - LLoTD, } \\
\text { - Damage length, } \\
\text { - CRDL, } \\
\text { - PCSAL, } \\
\text { - Coding: DFC, }\end{array}$ & Not described & Not described \\
\hline \begin{tabular}{|c|}
$\begin{array}{c}\text { Empty space between } \\
\text { the coating and the } \\
\text { original pipe }\end{array}$ \\
\end{tabular} & Not described & $\begin{array}{c}\text { - LLoTD, } \\
\text { - CRDL, } \\
\text { - Coding: LFAS, }\end{array}$ & Not described & Not described \\
\hline
\end{tabular}

How the damage in the form of complex wrinkling of the rehabilitation coating which obscures the cross-section of the pipeline by $15 \%$ and is located by the clock reference damage location from 12 o'clock to 5 o'clock can be described is presented below. This is one of the 4 types of damage on whose description allows all the presented methods. 
Table 2. Description of the above damage using the American method.

\begin{tabular}{|c|c|c|c|c|c|c|c|c|c|c|c|}
\hline \multirow{3}{*}{$\begin{array}{l}\text { Distance } \\
\text { (feet) } \\
\text { (meters) }\end{array}$} & \multirow{3}{*}{$\begin{array}{c}\text { Video } \\
\text { Ref. }\end{array}$} & \multirow{3}{*}{$\begin{array}{c}\text { Code } \\
\text { Group/ } \\
\text { Descriptor/ } \\
\text { Modifier }\end{array}$} & \multirow{3}{*}{$\begin{array}{c}\text { Continuous } \\
\text { Defect }\end{array}$} & \multicolumn{3}{|c|}{ Value } & \multirow{3}{*}{ Joint } & \multicolumn{2}{|c|}{$\begin{array}{c}\text { Circumferential } \\
\text { Location }\end{array}$} & \multirow{3}{*}{$\begin{array}{l}\text { Image } \\
\text { Ref. }\end{array}$} & \multirow{3}{*}{ Remarks } \\
\hline & & & & \multicolumn{2}{|c|}{ Dimension } & \multirow[b]{2}{*}{$\%$} & & & & & \\
\hline & & & & $1^{\mathrm{st}}$ & $2^{\text {nd }}$ & & & At/From & To & & \\
\hline 42.0 & & LFW & S01 & & & & & 12 & 05 & & $\begin{array}{l}\text { Complex } \\
\text { wrinkling }\end{array}$ \\
\hline
\end{tabular}

The PACP method for the damage under analysis does not describe the percentage of cross-section area loss of the pipeline, and does not have a code corresponding to the type of wrinkling. Instead, it provides the clock reference damage location, the damage code, the size of the damage, a description of the type of damage in the 'Remarks' box and the signs concerning the continuity of damage (S01 - the beginning of the damage).

Table 3. Description of the above damage using the British method.

\begin{tabular}{|c|c|c|c|c|c|c|c|c|c|c|c|c|c|}
\hline \multirow{3}{*}{$\begin{array}{l}\text { Video } \\
\text { Ref. }\end{array}$} & \multirow{3}{*}{$\begin{array}{c}\text { Photo } \\
\text { Ref. }\end{array}$} & \multirow{3}{*}{$\begin{array}{l}\text { Dist } \\
(\mathrm{m})\end{array}$} & \multirow{3}{*}{$\begin{array}{l}\text { Cont } \\
\text { defect }\end{array}$} & \multicolumn{4}{|c|}{ Letters } & \multicolumn{5}{|c|}{ Numbers } & \multirow{3}{*}{ Remarks } \\
\hline & & & & \multirow{2}{*}{ Code } & \multirow{2}{*}{ Joint } & \multirow{2}{*}{ Material } & \multirow{2}{*}{ Band } & \multicolumn{2}{|c|}{ Dimension } & \multirow{2}{*}{$\%$} & \multicolumn{2}{|c|}{ Clock } & \\
\hline & & & & & & & & 1 & 2 & & At/From & To & \\
\hline & & 42.0 & S01 & $\begin{array}{c}\text { LXW } \\
\text { C }\end{array}$ & & & & & & & 12 & 05 & \\
\hline
\end{tabular}

The WRc method for the damage under analysis does not describe the percentage of cross-section area loss of the pipeline. Instead, it provides the clock reference damage location, the damage code, the size of the damage occurrence and signs regarding the continuity of the damage (S01 - the beginning of the damage).

Table 4. Description of the above damage using the European method.

\begin{tabular}{|c|c|c|c|c|c|c|c|c|c|c|c|c|}
\hline \multirow{2}{*}{$\begin{array}{c}\text { Longitudinal } \\
\text { position }\end{array}$} & \multirow{2}{*}{$\begin{array}{l}\text { Continuous } \\
\text { defect code }\end{array}$} & \multirow{2}{*}{$\begin{array}{c}\text { Observation } \\
\text { code }\end{array}$} & \multicolumn{2}{|c|}{ Characteristic } & \multicolumn{2}{|c|}{ Quantification } & \multicolumn{2}{|c|}{$\begin{array}{c}\text { Circumferential } \\
\text { location }\end{array}$} & \multirow{2}{*}{\begin{tabular}{|l|} 
Joint \\
\end{tabular}} & \multirow{2}{*}{$\mid \begin{array}{c}\text { Photo } \\
\text { Ref. }\end{array}$} & \multirow{2}{*}{$\begin{array}{l}\text { Video } \\
\text { Ref. }\end{array}$} & \multirow{2}{*}{ Remarks } \\
\hline & & & 1 & 2 & 1 & 2 & 1 & 2 & & & & \\
\hline 42,0 & A01 & BAK & $\mathrm{D}$ & $\mathrm{C}$ & $15 \%$ & & 12 & 05 & & & & \\
\hline
\end{tabular}

The European method for the damage under analysis gives the percentage of cross-section area loss of the pipeline, the clock reference damage location, the damage code, the size of the damage occurrence and the signs concerning the continuity of damage (A01 - the beginning of the damage).

Table 5. Description of the above damage using the New Zealand method.

\begin{tabular}{|c|c|c|c|c|c|c|c|c|}
\hline $\begin{array}{c}\text { Video } \\
\text { Reading }\end{array}$ & $\begin{array}{c}\text { Distance } \\
\text { from }(\mathrm{m})\end{array}$ & $\begin{array}{c}\text { Distance } \\
\text { from }(\mathrm{m})\end{array}$ & $\begin{array}{c}\text { Condition } \\
\text { code }\end{array}$ & Severity & \multicolumn{2}{|c|}{ Position } & \multirow{2}{*}{ Photo No } & Remarks \\
\cline { 5 - 7 } & $\begin{array}{c}42.0 \text { (the } \\
\text { beginning of } \\
\text { the damage) }\end{array}$ & $\begin{array}{c}\text { (the end of } \\
\text { the damage) }\end{array}$ & PL, M & 25 & 12 & 05 & & $\begin{array}{c}\text { A detailed } \\
\text { description of } \\
\text { the damage }\end{array}$ \\
\hline
\end{tabular}

The New Zealand method for the damage under analysis gives a point scale corresponding to the risk that a given damage may cause (these points are awarded for all described damage to rehabilitation coatings based on the percentage of cross-section area loss of the pipeline), clock reference damage location, damage code and the size of the damage. 


\subsection{Discussion}

The damages that are fully described by all the methods analyzed are: bulging of the coating, its covering with blisters, separation of the coating from the walls of the renewed pipeline, improper finish of the coating and shrinkage of the coating; yet, only New Zealand and European methods give a full description of all these damages in the form of a longitudinal location of the damage, the length of the damage and its repeatability, clock reference location of the damage and percentage of cross-section area loss.

The analyzed damage classification indicates that the British method for any of the damages analyzed does not describe the percentage of cross-section area loss of the pipeline, the exception may be ovalization / deformation of the coating, although this classification is not explicitly described. In the description of the coding system for rehabilitation coatings in the American method, there is also no quantitative recognition of overlap, except for deformations in the form of rounded bulges (DFBR) and sharp curvatures with inverted curvature (DFBI), for the remaining damage there is a record that the column with a quantitative description of the damage is not used. In the other two analyzed methods, i.e. New Zealand and Europe, in the damage they describe, in which there is the possibility of a cross-section area loss of the pipe, this possibility of description exists. The lack of the percentage of cross-section area loss prevents an interpretation of the damage on the basis of the evaluation protocol itself and unnecessarily self-limits the method of defect description.

The method of damage description presented in Tables 2-5 shows the differences presented above, the British and European methods, take into account the complexity of the corrugation of the coating; while the American and New Zealand methods do not take it into account. The percentage of cross-section area loss is described in the British, European and indirectly in the New Zealand method, but is not included in the American method.

It is surprising that damage such as holes in the surface of the coating, exposed seam (CIPP), insufficient impregnation with resin (CIPP) or cracks and gaps in the coating, which seem to be one of the more obvious damages that a rehabilitation coating can suffer, are described only in one method - the British one. Other classifications may use codes related to damage to sewage pipes to describe some of these damages, although this is a erroneous approach, since, for example, a cracking of the renovation coating does not have to mean fracture of the parent pipe, especially as we know from the research described in [7-8] in most coatings, after some time of operation, there are circumferential spaces between the old pipeline and the coating, so a partial separation of the coating from the walls of the renewed pipe may occur.

As mentioned earlier, the most frequent damage to the rehabilitation coatings occurring after a longer service life, based on the tests described in [7-8], is the empty peripheral spaces between the coating and the renewed sewage pipe. In these tests, they fluctuated depending on the diameter and material of the pipe from $0 \mathrm{~mm}$ to approx. $13 \mathrm{~mm}$, they may arise due to the shrinkage of the coating during the curing process, or over time through the progressive corrosion of the parent pipeline or infiltration of water into the cavities already existing between the coating and the sewage pipe. As it turns out, only the American method allows a description of the most frequent damage, and although it is often impossible to check the occurrence of this type of damage during CCTV inspection, each method should be able to describe this type of damage.

\subsection{Conclusions}

1) Table 1 shows that in the 20 defects included in the statement, which occur in at least one of the 4 discussed methods, the British classification does not describe 4 damages, the American - 7 damages, the New Zealand - 15 damages, and the European - 13 
damages. Such large discrepancies may be due to the fact that the New Zealand and European methods, which describe much fewer types of damage, were developed 7-10 years earlier than the current versions of the British and American methods, although it was obvious that already then the technologies of rehabilitation coatings were known for over 40 years and have been widely used. It should be noted that all the listed classifications make it possible to describe the non-conforming damage by means of a special code denoting "other damage", or in the form of an annotation.

2) The most detailed text descriptions that explain what specific damage consists of are found in the American and British methods. In the European method, individual damages were only mentioned and the corresponding code was assigned to them, while in the New Zealand method there is general information about the group of described damages, giving them only one category which, depending on the damage, is supplemented with annotations in the inspection form.

3) None of the analyzed methods describes such damage to rehabilitation coatings as intersections of the coating (which have a different character than cracks or fissures), infiltration of groundwater through the walls of the rehabilitation coating and the presence of foreign bodies between the wall of the renewed piepe and the outer part of the rehabilitation coating.

4) Out of the analyzed damages, 10 out of 20 are included in only 1 out of 4 classifications, this shows the imperfection of the checked classification methods. This may indicate a lack of broader international consultations and exchange of experience between institutions dealing with this subject.

\section{References}

1. A. Kuliczkowski, Nowoczesne Budownitwo Inżynieryjne, 65, 51-55 (2016)

2. Praca zbiorowa pod red. A. Kuliczkowskiego: Technologie Bezwykopowe w Inżynierii Środowiska, wyd. Seidel-Przywecki, Warszawa, (2010)

3. A. Kuliczkowski, Problemy bezodkrywkowej odnowy przewodów kanalizacyjnych, Wyd. Politechniki Świętokrzyskiej, Kielce, (2004)

4. A. Kuliczkowski, U. Kubicka, NO-DIG 2006, Brisbane, Australia, (2006)

5. A. Kuliczkowski, U. Kubicka, Przegląd budowlany, 79, 56-61 (2008)

6. A. Kuliczkowski, GWITS, 02, 50-55 (2018)

7. E. Allouche, S. Alam, J. Simicevic, R. Sterling, W. Condit, J. Matthews, A. Selvakumar, TUST, 39, 82-93 (2014)

8. A. Shaurav, R. Sterling, E. Allouche, W. Condit, J. Matthews, A. Selvakumar, J. Simicevic, TUST, 50, 451-464 (2015)

9. National Association of Sewer Service Companies (NASSCO) Pipeline Assessment Certification Manual, USA, (2015)

10. WRc Manual of Sewer Condition Classification, Fifth Edition, UK (2013)

11. New Zealand Water and Wastes Association (NZWAA), Pipe Inspection Manual 3rd Edition (2006)

12. PN-EN 13508-2: Stan zewnętrznych systemów kanalizacyjnych Część 2: System kodowania inspekcji wizualnej (2006)

13. E. Kuliczkowska, Kryteria planowania bezwykopowej odnowy nieprzełazowych przewodów kanalizacyjnych, Wyd. Politechniki Świętokrzyskiej, Kielce (2008)

14. R. Błażejewski, R. Matz, GWITS, 06, 23-27 (2008) 